\title{
IMPROVING THE PROVISION OF PUBLIC SERVICES IN THE UNITED TERRITORIAL COMMUNITIES IN THE CONTEXT OF DECENTRALIZATION
}

\section{Svitlana Sliusar ${ }^{1}$ \\ Ludmila Levaieva}

DOI: https://doi.org/10.30525/978-9934-26-049-0-10

Abstract. In the context of the reform of decentralization in Ukraine, which envisages a set of changes, the main purpose of which is the transfer of significant powers and budgets from State bodies to local self-government bodies, the issue of providing high-quality public services to local selfgovernment bodies is extremely important. To do this, you need to first of all not only create the constitutional and legal foundations for improving the quality of public services provided by local authorities, but also expand their number. Methodology. During the writing of the paper, the following research methods were used: the search for available methodological and scientific literature, comparison, clarification of causal relationships, systematization, analysis of documentation and results of researchers' work on the problem of the conducted research and expert evaluation. Results. These processes require not only the renewal or improvement of the elements of the management system that do not function properly, but also a radical transformation of the mechanisms of the state, in particular legal and organizational and functional, ensuring the processes of regulation of decentralization, which is an important factor in achieving the effectiveness of public administration. Practical implications. This issue becomes even more relevant not only from the rosbalanciousness of the system of regulation of procedural elements in the relations of state and local authorities with citizens, but also because of the lack of a slender, clear and understood ideology of such relations, built on the principles of equality, openness and the rule of law. The solution to this problem is especially important in the

\footnotetext{
${ }^{1} \mathrm{PhD}$ (Economics), Associate Professor,

Pereiaslav-Khmelnytskyi Hryhorii Skovoroda State Pedagogical University, Ukraine

${ }^{2} \mathrm{PhD}$ (Economics), Associate Professor,

Pereiaslav-Khmelnytskyi Hryhorii Skovoroda State Pedagogical University, Ukraine

(C) Svitlana Sliusar, Ludmila Levaieva
} 
context of the formation of civil society - it is the quality of administrative services and the qualification of their provision that is evidence of the attitude of the entire mechanism of state power to the person, the degree of respect for his rights and freedoms. Value/originality. The paper proposes to adopt a code «On public services» in order to improve public relations in the provision of public services by subjects of public administration, analyzed legal and regulatory acts on the basis of which local authorities provide public services, as well as legislative acts that define standards for the provision of public services.

\section{Introduction}

The modern stage of the development of Ukrainian society was affected by the active introduction of European standards, a change in the principles of $i$ forms of relations between the authorities and i society (citizens), the introduction of a new philosophy of public management, the essence of which is not in the management of society, but in the provision of services, in the «service» to the interests of society i person. In the light of recent events in Ukraine, the question of establishing and improving the institution of public services as a determining factor in ensuring the realization of the rights and freedoms of citizens becomes especially relevant. However, despite numerous achievements in democratic changes, there was still no clear regulation of the procedural aspect of the relations of person $i$ of power, the principles of the activities and responsibility of public authorities in the provision of public services were not defined, the issue of their payment was not resolved.

In connection with the development of socio-economic, legal, organizational and political transformations in Ukraine, the provision of various public services by local authorities and their officials is increasingly troubling society. Practice shows that local self-government bodies and their officials impose various additional, mainly paid services on citizens. Additional public services are not necessary to obtain in the area of additional public services of the State, which, according to world experience, can be paid in the amount of their cost, and money for their payment can be sent either to the budget in the form of a state fee or to the maintenance of the bodies that provide them. However, one of the dangers of additional services is the commercialization of the state apparatus. Thus, 
the decisions of some local authorities, which in the slogans of the «fight against corruption» legalize the collection of fees for a particular service, or do not benefit the consumer at all, or should be provided free of charge, raise doubts.

The procedure for the evaluation of public services should be clearly defined. Public service centres should be concentrated in local governments. Public services provided by local governments should be free of charge. The resolution of this issue at the legislative level will help to combat manifestations of corruption. The creation of convenient and accessible conditions for obtaining public services is one of the main tasks, it has to be solved by local authorities.

\section{Legal nature of public services}

Ukraine, as a democratic state, has chosen a course on European integration, one of the three priority areas of reform was decentralization. The constitutional dimension of decentralization is embodied in the realization of the principle of popular sovereignty. The official government website on the reform of decentralization of power defines decentralization as the transfer of significant powers and budgets from state bodies to local selfgovernment bodies, so that as many powers as possible have those bodies closer to people where such powers can be exercised most successfully [6].

Based on the definition, the main goal of decentralization in Ukraine is to strengthen the role of local self-government, to give representative bodies of territorial communities a large amount of authority to manage local affairs, and to deprive local state authorities of the authority to prepare and fulfill district and regional budgets. Playing an important role in the activities of local self-government bodies and the legal basis for decentralization of power, the Law of Ukraine «On Local Self-Government in Ukraine» [10] and other regulatory legal acts.

In general, the reform of local self-government and decentralization of power in Ukraine should be noted such its main goals. The first goal is to complete the formation of an optimal system of administrative-territorial structure for Ukraine; the second objective is to provide accessible and quality public services to local government; the third objective is that communities will be involved in local issues; the fourth objective of decentralization is that financing regional policies will ensure the 
development and competitiveness of communities and regions; the fifth objective is that the State will monitor the legality of local self-government.

Thus, decentralization, as one of the priority reforms in Ukraine, provides for the strengthening of the role of regional government bodies and local self-government in the implementation of economic and structural reforms. It accelerates the diversification of the territorial economy, the optimization of the management of state and communal property, the development of interregional and cross-border cooperation in various areas of public life.

We believe that, in the context of the decentralization of power, it is necessary at the legislative level to resolve the issue of the transfer of authority from the executive authorities to local authorities to provide basic public services to residents of territorial communities. In turn, public authorities and officials of local self-government bodies should be subject to appropriate control (supervision) regarding the quality of public services.

In the context of decentralization of power, among many normative legal acts, the «Concepts of reforming local self-government and territorial power in Ukraine» № 333-r April 1, 2014, which notes that the system of local selfgovernment does not meet the needs of society today, plays an important role. The functioning of local self-government bodies in most territorial communities does not ensure the creation and support of a favorable living environment necessary for the comprehensive development of a person, his self-realization, protection of his rights, provision to the population of local self-government bodies, institutions created by them and organizations of high-quality and accessible administrative, social and other services in the respective territories $[2$, p. 6,12$]$.

The Concept states that public services should be provided in accordance with state standards, taking into account the need to ensure: territorial accessibility, providing for the provision of services in the territory of the community where the person lives; adequate logistics for the provision of basic forms of public services; openness of information on services, procedure and conditions of their provision; professionalism in the provision of public services [12].

The issue of a public contract is given considerable attention by scientists and legal practitioners, which is due to its use in the practical activities of local self-government bodies by providing public services to citizens and legal entities and the unresolved issues that exist in their provision both from a scientific 
and practical point of view. The specific means of carrying out management activities through the provision of public services and the recent adoption of new regulations governing these relations make the study more relevant.

The introduction of a new view of the role and activities of local selfgovernment bodies and their officials should be aimed at creating an enabling environment for the development of civil society and the strengthening of democracy, should constitute daily activities to provide high-quality administrative services to residents of the territorial community. Such activities should be based on a person-centric ideology.

Today, it is the administrative contract, which has legislative regulation, that is important in the system of legal relations between local selfgovernment bodies and individuals and legal entities. In essence, most administrative contracts are of a comprehensive nature, regulated by the norms of various branches of law, of which civil, economic, financial, land, environmental law and the like occupy a special place. The application of an administrative contract by the competent authority is a mandatory feature. Thus, the local government body in the administrative contract acts as a subject of public law, its status is determined by its competence.

Based on the fact that an administrative contract is a form of a public law contract and occupies an intermediate place between an act of a State authority and a private law contract, the mandatory subject of which is the subject of power. It is a state authority, a local self-government body, their official or official person, another entity in the exercise of public-power managerial functions on the basis of legislation, including the exercise of delegated powers, or the provision of administrative services [5, p. 47; 7]. Thus, the above provides grounds to state the need to apply precisely the term «public contract» instead of the term - «administrative contract».

At the same time, depending on the subject, provides public services, distinguish between state and municipal services. So public services can be provided by state authorities (mainly the executive branch) and state enterprises, institutions, organizations, as well as local self-government bodies in the exercise of delegated powers by the state at the expense of the state budget, while municipal services are provided by local selfgovernment bodies, as well as executive authorities and enterprises, institutions, organizations in the exercise of delegated powers by local selfgovernment bodies at the expense of the local budget. 
Thus, an important component of both public and municipal services is administrative services [14, p. 303-305], as well as public services. Public service is the activity of a subject of public administration, which is carried out at the request of an individual or legal entity $i$ aimed at ensuring (legal registration) of the rights and interests of the applicant of the service. Public services are provided by local authorities directly or through administrative service centres established by them. In addition, public services can be provided in electronic form through a single state portal of administrative services, including through integrated information systems of state bodies and local authorities.

According to the definition of the term «public services,» in accordance with the Concept for the Development of the System of Providing Administrative Services by Executive Bodies, approved by Cabinet of Ministers Order № 90 of 15 February 2006, the scope of public services consists of services provided by State authorities, local authorities, enterprises, institutions and organizations that are in their management. The above, once again confirms the need for Normatin to apply a unified period of «public service,» instead of: state, administrative, municipal.

With the development of public relations at the present stage, it is safe to say that contractual regulation has found its main place in the activities of local governments. The successful development of the provision of quality public services by local self-government bodies and their officials will occur subject to the existence of public service centers that organize and provide consulting, mediation and information services and other types of services in the field of local self-government.

Considering different definitions of the concept of «public service,» we provide the Author's definition of this concept. Public service is the result of the activities of local self-government bodies, their officials called up, which is provided on the basis of a person's application in order to realize the rights and legitimate interests of citizens (the interests of the territorial community) in the field of activities of public administration entities.

In the most general sense, the legal prerequisites for concluding a public contract are socio-economic, legal and other changes in the field of activities of public administration entities, which include local governments. The result of democratic changes, decentralization of power, in turn, could not affect the expansion of the scope of use of the public contract. Contractual 
relations in the field of local self-government activities today have not yet received the corresponding legal formality. At this stage, you can only observe individual elements that resemble a contractual relationship. However, only in some cases do they approach the concept of contractual relations in nature.

By its legal nature, the type of legal prerequisites for concluding public contracts is the «foundation» for the construction of contractual legal relations, their separation from other types of legal relations that take shape in the process of organizing and operating subjects of public administration. This group of legal prerequisites is closely intertwined with the normative prerequisites for concluding a contract and specifies their requirements in relation to specific types of public contracts in a particular area of public law regulation, in particular in the activities of local self-government.

An example of the competent prerequisites for concluding a public contract may be the norm enshrined in article 5 of the Law of Ukraine «On Product Sharing Agreements» according to which «the Parties to the agreement on the distribution of products are an investor (investors) and the state represented by the Cabinet of Ministers of Ukraine. The Cabinet of Ministers of Ukraine shall form a standing interdepartmental commission composed of representatives of State bodies, local self-government bodies and people's deputies of Ukraine» [13].

It is also worth noting that the executive authorities and local selfgovernment bodies, when implementing the Law «On Agreements on the Division of Products» in accordance with their powers, carry out their activities on the principles of cooperation and cooperation in order to protect the interests of the people of Ukraine, the state, regions and territories, ensure the protection of the environment $i$ rational use of the subsoil and other natural resources of Ukraine. Coordination of the activities of executive authorities and local self-government bodies during the conclusion, execution and termination of agreements on the distribution of products is carried out by the Cabinet of Ministers of Ukraine within its powers and taking into account the provisions of the Law «On Agreements on the Division of Products» [13].

In this case, the subjects of public administration, to which we also include local governments, first of all, they themselves develop a public contract, establish the conditions for its conclusion, establish the responsibility of the parties, rights and obligations, and the like. It also depends, both on the subjects of conclusion to the court, and on the subject of the contract. In the matter of 
procedural prerequisites with which the law connects the conclusion of a public contract, they include the procedure of the local government body of the decision to commit power (management) actions in the form of a contract, conducting auctions, competitive bidding for the selection of a legal or natural person, would meet the requirements of the contract that are submitted to its parties, agreeing on the conclusion of an administrative contract with a supervisory authority, determining the winner of the competitive bidding, auction and conclusion of a contract with it, and the like. At the same time, regardless of the object of the contract, proposals to conclude a public contract are always expressed in writing and must contain all significant conditions determined by regulatory acts for contracts of this type, be addressed to a specific subject (s) of public law and contain an express intention to create public contractual obligations.

\section{Local governments as public service providers}

In the context of decentralization of power, one of the main tasks that local governments today have to solve is to create convenient and accessible conditions for individuals and legal entities to receive high-quality public services. The regulations in force guarantee to all citizens a variety of public services, regardless of age, social status or place of residence. At the same time, today it is obvious that the provision of services in Ukraine at the local level does not fully meet the needs of the development of society in general and every citizen in particular. It is the local factor in the provision of services that becomes decisive in building confidence in the authorities, so it is the local governments, their officials as subjects of public services and, who are the closest to citizens, who are called upon to ensure the quality and efficiency of public services.

The public confidence in the local government system depends on the provision of quality, safe, accessible, in-demand services to local governments. In this context, an adequate understanding of ways and means of providing quality and timely services to consumers by local governments is essential. The importance of such understanding is reinforced by the reality of the provision of public services in Ukraine, since sometimes citizens are unsatisfactory with the quality, complexity and non-openness of the relevant procedures for the provision of services.

In any sphere of public relations, standards are necessary and established by relevant regulations. In general terms, the term «standard» is interpreted as a model, template, stencil, standard that has nothing original and is 
accepted as the source for comparing other such objects with it, or as a regulatory and technical document establishing units of measure, the timing of their determination, requirements for services, etc. [3, p. 78]. Unlike the doctrinal definition, there is a normative definition of this concept. The Law of Ukraine «On Standardization» provides this definition: the standard is a normative document based on consensus, adopted by a recognized body, establishing for the general and repeated use of rules, instructions or characteristics on activities or their results, and is aimed at achieving the optimal degree of consistency in a certain area [11].

According to article 5 of the Standardization Act, the purpose and objects of standardization in Ukraine are to ensure that objects of standardization meet their purpose; diversity management, applicability, compatibility of standardization objects; Ensuring sound production through the application of recognized rules, policies and procedures; Ensuring the protection of life and health; ensuring the rights and interests of consumers; ensuring carelessness of work; conservation of the natural environment and saving of all types of resources; elimination of technical barriers to trade and prevention of their occurrence, support of product development and international competitiveness [11]. Using the information provided in the standard, the administrator will be able to clearly and correctly build a dialogue with the visitor so that the latter is satisfied. The standard is the main tool for adapting new employees in the team. It allows you to clearly structure the process of working with the visitor during maintenance. Compliance with the standard affects the formation of the image of the center for the provision of administrative services (ASC), and a positive image is the trust of visitors. The standard is a collection of rules, requirements and recommendations for quality services for visitors to administrative service centers. The standard regulates the activities of administrators of administrative services centers as part of the process of servicing visitors. The standard is recommended for use in administrative service centres at all levels throughout Ukraine [1, p. 6].

At the same time, administrative services are provided in accordance with standards approved by the providers in accordance with their authority. At the same time, budgetary institutions, to which the authority to provide administrative services is delegated under regulatory acts to the executive authorities, provide such services in accordance with standards approved by the executive authorities, which delegated such powers to them. If the 
right to provide administrative services is granted to two or more entities, including local executive authorities, territorial bodies of central executive authorities, the central executive authority responsible for the provision of administrative services approves a typical standard for the provision of administrative services, according to which other entities approve their own standards for the provision of such services. The study showed that the substance of the standard of administrative service can be considered from two points. On the one hand, this is an act that is issued by the subject in accordance with regulatory legal acts governing the procedure for providing administrative services, and contains information about the administrative service and the procedure for providing it, in particular the conditions and responsible persons. On the other hand, this is a set of requirements for the provision of administrative service, which the administrative body must provide, and criteria by which it is possible to assess how satisfied the user of the administrative service is with its provision. At the same time, the standard should include requirements that ensure the necessary level of accessibility and quality of the administrative service as a whole, as well as at each stage of its provision, including the submission of a request for the provision of an administrative service, its registration and registration, waiting for the provision of an administrative service, its receipt, control over the quality of the administrative service [8].

It follows from the above that this refers to public services provided by local authorities. To public services, in particular belong: issue of licenses, permissions and other documents of allowing character, certificates, certificates, certificates, certificates; registration (facts, subjects, rights, objects, including legalization of subjects and acts (documents), nostrification and verification) of other activities regardless of name, as a result of which interested individuals and legal entities, as well as objects owned, owned or used by such persons, are granted or confirmed a certain legal status and/or fact. Standards of relevant administrative services are approved at different levels of government: central (by order of the relevant ministry or other central executive body); regional (by order of the chairman of the regional state administration) local (local authorities). In particular, by order of the Ministry of Justice of Ukraine of August 31, 2009 № 1555/5, standards for the provision of administrative services were approved. However, the disadvantage of the approved standards for the provision of administrative 
services by the Ministry of Justice of Ukraine is that there is no such entity for the provision of administrative services as local authorities.

The above requires that each local government body develop its own Concept for the provision of public services, which they already provide and can continue to provide to citizens, and such services should be free of charge for citizens living in the United Territorial Community. In addition, public service providers who do not meet the established standards must be personally responsible for a service that does not meet the standards.

\section{Conclusion}

Based on the analysis of the provision of public services by local authorities, we believe that in the context of the decentralization of power, it is necessary at the legislative level to decide on the transfer from the executive authorities to the local authorities of the authority to provide basic public services faced by residents of territorial communities. It is advisable to transfer to local authorities the provision of public services in such areas as: registration of the place of residence of citizens; registration of legal entities and individual entrepreneurs, public associations; provision of utilities and housing services; provision of land services; provision of employment services for community citizens.

In order to improve public relations in the provision of public services by subjects of public administration, we propose to adopt a code «On public services,» which should regulate both the general procedure for the provision of public services and regulate the procedure for resolving cases on applications of individuals and legal entities to public authorities.

Legal and regulatory acts on the basis of which public services are provided by local authorities have been analyzed. It is proved that the basis for the provision of public services is the conclusion of a public contract. The signs of which are characterized by public services provided by local authorities are described. Public service is the activity of a subject of public administration, which is carried out at the request of an individual or legal entity and aimed at ensuring (legal registration) of the rights and interests of the applicant of the service. Legislation has been analysed that sets standards for the provision of public services and establishes that public services provided by public administration entities must meet national and international standards. Persons providing public services and who do not meet the established standards shall bear personal responsibility. 


\section{References:}

1. Andryeyev A., Kamenchuk O., Semenikhin V., and Shamray N. (2017) Yedyni vymohy (Standart) rekomendovani do zastosuvannya tsentramy nadannya administratyvnykh posluh usikh rivniv po vsiy terytoriyi Ukrainy [Uniform requirements (Standard) recommended for use by centers for the provision of administrative services at all levels throughout Ukraine]. Kyiv.

2. Bryhilevych I. (2017) Diyal'nist' CNAP ta otsinka yakosti nadannya administratyvnykh posluh [Activities of ASC and assessment of the quality of administrative services]. Kyiv.

3. Vasyl'yeva O. I., Vasyl'yeva N. V. (2012) Standartyzatsiya nadannya administratyvnykh posluh $v$ Ukrainy [Standardization of administrative services in Ukraine]. Kyiv: University science notes.

4. Constitution of Ukraine: Law of Ukraine 1996. Holos Ukrainy, 28 June, p. 141.

5. Lys A. B. (2015) Svitovyy dosvid nadannya posluh naselennyu derzhavnymy $i$ samovryadnymy orhanamy vlady [World experience in providing services to the population by state and self-governing authorities]. Kyiv: Public administration.

6. Community unification. Decentralization of power. Available at: http://decentralization.gov.ua/region.

7. On amendments to the Economic Procedure Code of Ukraine, the Civil Procedure Code of Ukraine, the Code of Administrative Procedure of Ukraine 2017: Law of Ukraine, 03 Octob. Available at: http://zakon2.rada.gov.ua/laws/ show/2147-19.

8. On approval of the Methodological Recommendations for the Development of Standards for Administrative Services: Order of the Ministry of Economy of Ukraine № 219 of 12.07.2007. Available at: http: //www.adm-pl.gov. ua/page/metodika-standartivnadan-nya-adminposlug

9. On the approval of standards for the provision of administrative services: Order of the Ministry of Justice of Ukraine № 1555/5 of 31.08.2009. Available at: https://www.google.com.ua/search?q

10. On local self-government in Ukraine: Law of Ukraine of 21.05.1997. Vedomosti of the Verkhovna Rada of Ukraine. 1997. № 24. Article. 170.

11. On standardization: Law of Ukraine of 05.06.2014. Vedomosti of the Verkhovna Rada of Ukraine. 2014. № 31. Article. 1058.

12. On the approval of the Concept of reforming local self-government and the territorial organization of power in Ukraine: Order of the Cabinet of Ministers of Ukraine № 333-r of 01.04.2014. Available at: http://zakon4.rada.gov.ua/laws/ show/333-2014-p

13. On agreements on the distribution of products: Law of Ukraine dated 14.09.1999. Vedomosti of the Verkhovna Rada of Ukraine. 1999. № 44. Article. 391.

14. Svitlychnyy O. P. (2011) Administratyvni pravovidnosyny u sferi zemel'nykh resursiv Ukrayiny: problemy teoriyi ta praktyky pravozastosuvannya [Administrative legal relations in the field of land resources of Ukraine: problems of the theory and practice of law enforcement]. Donetsk: State publishing house «Donbass». 